\title{
The Relationship between Servant Leadership Characteristics of School Teachers and Students' Academic Achievement
}

\author{
Harun Gultekin ${ }^{1}$ and Margaret Dougherty \\ Alvernia University, USA
}

\begin{abstract}
This study is a quantitative non-experimental design to explore the relationships between servant leadership characteristics of teachers and academic achievement of students in selected public schools. The purpose of this research was to explore the relationships between servant leadership characteristics of school teachers and students' academic achievement in selected public schools. The hypothesis for this study was that, in the selected schools, the servant leadership of school teachers positively affects students' academic achievement. The data collected in fifteen public schools located in Houston, Texas. As an instrument, the Organizational Leadership Assessment (OLA) was used in this study (Laub, 1999). This instrument has 66 questions with Likert-scale responses ranging from strongly disagree to strongly agree, and data was collected from 362 participants. The servant leadership data was gathered through the OLA survey and interpreted as distinguishable factors that contribute to the larger picture: servant leadership. As our hypothesis, servant leadership behavior and student achievement are expected to have correlation. To understand the relationship between student achievement and servant leadership, univariate and multivariate analysis were used. The data was screened for normality, linearity, and homoscedasticity. Data analysis was conducted by using SPSS Statistics version 22.0, as the tools for the analysis of this research. As a result of the OLA survey regarding the functions of servant leadership, the values people subscale became statistically significant. It is the only subscale that showed any extensive correlation with academic achievement. The scale may indicate how much a teacher values people.
\end{abstract}

Keywords: academic achievement, non-experimental design, servant leadership.

Education is a continual process that is open to alteration. The United States Congress has reviewed the Elementary and Secondary Education Act (ESEA) six times since 1965, and educational reforms are continually authorized through the Congress. The No Child Left Behind Act (NCLB) was in place until 2010. After the NCLB Act, President Barack Obama released $A$ Blueprint Act to re-authorize The Elementary and Secondary Education Acts. This current reform specially focuses on priorities such as preparing students for college and careers, improving teachers' leadership capabilities, providing equality, and increasing rewards for success and improvements. All of these policies rely on data-driven decision making.

According to Elmore (2000), schools have both a dynamic and a static structure. For Elmore, it is essential to understand a school's structure, the roles of its leaders, and the school

${ }^{1}$ Corresponding Author E-Mail: harungultekin@yahoo.com 
environment. This can lead to improvements in climate in a context of school leaders and students learning together (Elmore, 2000). As an example; Mcalpin et al. (2019) mentioned the flipped classroom model that students learn at home through online coursework, lectures and teachers use class time for facilitating class projects. Giannakos et al. (2018) indicated in their research that this model of teaching increased learning performance, attitudes, and engagement.

Also, Curless (2000) pointed out that teaching philosophies may affect teaching and learning processes. To respond to the complexities of their role and the difficulties in teaching routines, teachers have to understand teaching and learning processes and must improve and adopt new educational paradigms that are continually constructed, refined, adjusted, and renovated.

In a study titled The Servant as Leader, Greenleaf (1970) coined the term servant leadership, which means supervising people more by serving them rather than directing them. Servant leaders consider other people's needs more than their own. They see other people as valuable assets to society, so they build respectful and trusting relationships with them to foster their personal growth. In the context of this study, teachers and school leaders are seen as role models.

Moreover, Spears (2005) indicated that servant leadership has gained strength and adherents for more than three decades. He identified the characteristic of servant leaders that is serving people first based on Greenleaf's (1970) original writings. There are few studies about servant leadership among teachers; more research about this topic might be necessary. Thus, this study will focus on correlations between servant leadership of teachers as leaders and students achievement by using a non-experimental quantitative methodology.

Effective leadership in schools implies promoting processes that improve the teaching and building of a relational trust in the school community. Spears and Lawrence (2016) identified that in the context of the school, three aspects of leadership must be taken into account: pedagogical leadership, distributed leadership, and moral leadership.

Pedagogical leadership implies that managerial competencies are aimed at creating conditions and promoting organizational and professional contexts that improve teaching and learning processes. While the management of a school performs management and administration tasks, its central mission is teaching. That is why it should focus its efforts on improving the education offered by the school (Shaw \& Newton, 2014). Management enhances teaching and learning through its influence on staff motivation, commitment, and working conditions.

Distributed leadership is a type of leadership in a school that requires alliances among the members of the community and precise orientation of where to move forward. In this sense, participation is fundamental. A leadership that combines more authentic involvement and more commitment will be better led if it is in a network and in a distributed way (Northouse, 2018). Distributed leadership implies that the members of a school share decision-making; it implies that each member feels empowered and committed to the processes of change and improvement in the center.

Moral leadership in schools works best when there is a climate of trust, and where members - especially teachers, but also students and parents of families - feel they are part of a community (Hall \& Quinn, 2014; Rasool \& Zhang, 2020; Thompson, 2015). Leading in this sense implies dedicating time to the care of the group. The managers must take care of the space of coexistence where democratic values are present. Leadership is needed in the construction of values that give meaning to the center as a collaborative project and as a community.

Conventional leadership models primarily focus on aspects of leadership behavior and personality as critical determinants of leadership success. They fail, however, to explore more deeply the sides of leaders and their followers as human beings, with their values, inner needs, and 
inner motives (Sousa \& Van Dierendonck, 2016). In this context, the theory of servant leadership presents itself as a response to this gap, emphasizing that it is an important essence of the development of people and their fulfillment, whose growth and well-being are the ultimate goal.

Thus, to be a leader means to be a person at the service of others, to have personal fulfillment in the accomplishment of the companions, and it is essential to see the growth and progress of their followers through their advancement and development. Moreover, it is also vital to ensure the well-being of each person. Thus, the leader grows with the vision of promoting within others.

According to Jaramillo et al. (2015), senior leaders need to understand that their role is to help people achieve their goals. They continually try to put the vision into practice and to discover the needs of their people to perform well. Servant leaders do not want employees to be like them, but they want to make a difference in employees' lives, as well as to make a positive impact on the organization. According to Al-Mahdy et al. (2016), servant leaders see people as a whole: body, heart, mind, and spirit, and work to unleash their full creative potential.

There are many studies and concepts on the topic of leadership, but most of them are wrapped in the same existing models that are no longer yielding satisfactory results. The servant leadership model is gaining strength in organizations, as its effects are becoming more and more visible (Brown \& Bryant, 2015). Therefore, it was found that thinking and caring about people were determining factors in leaders significant influence on them.

Organizations that already had a vision of the future started to use this model and realized that this form of leadership became a new model for organizations (Grisaffe et al., 2016). Unlike many of the earlier leadership styles, application of the servant leadership model in some organizations has obtained greater returns than in others. In this context, the purpose of this study is to explore the relationships between servant leadership characteristics of school leaders and students' academic achievement in selected public schools. In this study, servant leadership behavior, measured by the Organizational Leadership Assessment (OLA) (Laub, 1999), is the independent variable, to be correlated with student achievement, which is the dependent variable. Students' academic achievement was defined based on standardized test results of mathematics, reading, science, and social science in Houston, Texas. In the United States education system, it is believed that characteristics such as humaneness, thinking of others, and servant leadership in teaching may be important. These characteristics may improve educational success and role modeling for others (Bandura, 1977). In this regard, the relationship between servant leadership behavior and students' achievement in the public-school districts in Houston, Texas was studied. The characteristics of servant leadership were examined in teachers. Because, few quantitative studies have been conducted to measure the relationship between servant leadership and educational success, this study may provide a model for the application of servant leadership in educational institutions.

\section{Theoretical Framework}

Bandura's (1977) social learning theory (SLT) was used as the conceptual framework for this study. Social learning theory was first developed in the late nineteenth century. According to the theory, people learn from one another through observation, imitation, and modeling. Bandura introduced social learning theory terminology into the field of education in the 1960s. He stressed the importance of the centrality of observing and modeling the behaviors, attitudes, and emotional reactions of others. 
Bandura explained that if people had to rely solely on trial and error to learn, it would take a long time to learn even simple tasks, likewise, the importance of modeling and the influence that others have on behavior were noted by Eggen and Kauchak (1997). Bandura (1986) explained that people are capable of symbolizing, self-regulating, self-reflecting, having forethought, and learning through modeling. They are not only reactive to situations, but also proactive and anticipative, and they function as regulators and self-evaluators of motivations and actions (Bandura, 2001). In other words, people are organisms with aspirations and a capacity for anticipatory self-control regarding behavior. They are not machines; people can anticipate and initiate their behaviors (Bandura, 2001). Many of the concepts in social cognitive theory can be applied to individuals' thoughts and actions regarding servant leaders and their interactions with the people they lead. For this study, it is believed that Bandura's social cognitive theory can help us to understand servant leadership. Bandura (1977) indicates that most human behaviors are learned observationally through modeling, and that teachers are natural role models, which helps them to prepare students for the future. Teachers can be servant leaders in the classroom, and their leadership should contribute positively to students' performance and the general atmosphere at the school. In this context, there are different styles of leadership, and each has its strengths and weaknesses. The main types of leadership are democratic, autocratic, liberal, and charismatic (Panaccio et al., 2015). On the other hand, servant leadership brings a new way of leading people, making them an essential part of the processes that are inserted. Therefore, it is important to highlight some of the characteristics of the central leadership styles to see how the servant style differs in terms of its origin, performance, and perspective (Yang et al., 2018).

In the democratic style of leadership, the whole group can and should contribute ideas. The responsibility of the democratic teacher in schools is to advise the opinions so that in practice teachers can reach the expected objectives. The group comes to understand that achieving the goals is everyone's responsibility (Winston \& Fields, 2015). The teacher with this style generally has a balanced concept of himself and does not fear that others have led better than him in certain aspects. The difficulty with this style is the potential for delay in decision-making during times of crisis.

Autocratic leadership is characterized by trust in authority, and presupposes that others will do nothing unless commanded. An autocratic leader usually does not care what other leaders think, thus discouraging innovation. He deems himself indispensable, showing that only his way of doing things is correct. Autocratic leaders take an often-paternalistic stance, feeling happy to realize that others depend on them. They rarely delegate service that is centralization and most significant feature of the autocratic leadership. With this style, anger, irritation, and incomprehension of mistakes by others are common. Decisions are made swiftly, which is very positive way to be accepted by subordinates. However, when an autocratic leader ends their term, the group is often lost because it is not accustomed to making its own decisions, creating a vacuum in the power of command.

Liberal leaders believe that their primary job is the maintenance of what has already been achieved. They do not give orders, do not draw objectives, and do not guide other leaders, letting things run as-is. It is common to find leaders disagreeing with such attitude (Selladurai \& Carraher, 2014) and people who tend to leave the group usually exercise this style of leadership. They do not want to have the job of organizing, planning, and overseeing. In many cases, they were elected because no one wanted the job or because they wanted only the title of leader, not having the will to lead.

A charismatic leader is that leader who comes in the middle of the group by empathy and positive influence. Usually, the members themselves identify the charismatic leader even before himself is aware of his role. The charismatic leader cares about people, is ethical, and has good 
communication skills. This type of leadership can be known as natural leadership. This type might closely resemble the leader of the future as the servant leader (Selladurai \& Carraher, 2014).

\section{Methodology}

\section{Research Design}

This research is aimed at answering the proposed research problems adequately. Developing a research design involves drawing a blueprint for the collection, measurement, and analysis of obtained data for the research (Creswell \& Creswell, 2017). Accordingly, the research problem dictates, which research design, is to be chosen. There are different types of research designs to address the research questions. These include qualitative, quantitative, and mixed methods research designs. The quantitative research considers that knowledge must be objective and previously formulated hypotheses are tested, thus through a deductive process, including numerical and inferential statistical analysis. This approach bases its research on type cases, with the intention of obtaining results that allow for generalizations (Creswell \& Creswell, 2017).

In this research, a quantitative methodology is being used. A quantitative method design aimed at addressing the research question by using numeric or quantifiable data or information is employed. Additionally, with a quantitative method research design the researcher can address the research questions more comprehensively.

This study utilized a quantitative approach to test the hypothesized relationship between servant leadership and students' academic achievement. The design included several forms of descriptive statistics, univariate correlation analyses, cross-tabulations, and simple and multiple regression analyses. Data was obtained from the databases of selected public schools, directly through surveys of the school leaders as teachers. The main set of results is based on a regression analysis of the survey data (for the independent variable) and the student achievement data (for the dependent variable). In the regression model, several variables were controlled to ensure that the hypothesized relationship between servant leadership and student achievement is not mitigated by other possibly intervening variables. The educational areas were selected by well-known variables that are typically used in the educational assessments of student achievement, such as state standardized test scores like the State of Texas Assessments of Academic Readiness (STAAR) for math, reading, writing, science, and social sciences.

\section{Research Questions and Hypothesis}

The following research questions were addressed in this research: In public schools, how are students' math, science, reading, social science achievement scores influenced by the servant leadership style of school teachers?

The data were collected in each math, science, reading, and social science variables and were analyzed.

This study hypothesizes that in the selected schools, the servant leadership of school leaders and teachers affects students' academic achievement. All those four variables; math, science, reading, and social science were hypothesized analyzed separately and their effects were studied.

This study was conducted using a sample of selected public schools in three districts in Houston, Texas. The details of the schools' demographics and other data were collected after acquiring approval from the IRB. The researchers approached the 1096 potential participants for this study, consisting of teachers. In accordance with convenience sampling procedures, the 
information related to the recruitment of research participants was sent online. The sample size considered for this research might not be representative of all of the schools, or of the public-school system; however, the outcomes of this research are anticipated to be generalizable to a set of public schools having similar size and student composition. Moreover, the results are also expected to be representative of public schools in states with similar socioeconomic and demographic characteristics.

\section{Variables}

For this research, the dependent variable is student achievement, which was measured using state data from standardized tests. This variable was also compared with average relevant state data. The independent variable is the level of servant leadership, which was correlated with the Organizational Leadership Assessment (OLA) data. Moreover, to ensure that we singled out the relationship between servant leadership and student achievement, various other variables were also considered for this research. The control variables included the size of the school, the proportion of low-income students, the teacher-to-student ratio, the average teacher salary, the average class size, and the gender of the participants. This list of control variables was further adjusted depending on the availability of data and the permission granted by the school administrators for accessing and using data in research. To the extent that servant leadership might be an important factor in student achievement, the coefficients of this variable are expected to remain statistically significant, even after the inclusion of these control variables in the regressions.

\section{Instrumentation}

Laub's (1999) Organizational Leadership Assessment (OLA) was used as an instrument. Laub developed this instrument to assess the characteristics of servant leadership. It is one of the most commonly used instruments and has been employed effectively in several leadership studies. It is well suited to analysis in an educational context like the one used in this study. Laub (1999) indicated that the cumulative instrument reliability was .98. Horsman (2001), Thompson (2015), and Ledbetter (2003) also conducted reliability tests for the OLA and reported equal or higher scores of reliability. Also, Miears (2004), using the OLA, obtained a comparably high-reliability score of .987 (Laub, 1999). The OLA was established through the demanding Delphi Survey research process, which utilized a panel of 14 servant leadership professionals who came to an agreement that the three parts of the Delphi process assessed the characteristics of servant-minded organizations. These characteristics are clustered into six main areas that relate to how a healthy organization functions (Laub, 1999): values people, shares leadership, develops people, builds community, displays authenticity, and provides leadership. The OLA consists of 66 survey questions using a five-point scale $(1=$ no response or undecided, $2=$ strongly disagree, $3=$ disagree, $4=$ agree, $5=$ strongly agree). It is important to note that the OLA educational version was used in this study; this instrument is essentially the same as the original version but uses titles and wording relating to a school environment (Laub, 1999). As in the OLA survey, the results regarding the functions of servant leadership_values people, shares leadership, develops people, builds community, displays authenticity and provides leadership - are interpreted as distinguishable factors that contribute to the larger whole: servant leadership. 


\section{Data Collection}

A researcher has two possible types of information and data needed to achieve the objectives of the research, which includes primary and secondary data. The primary data corresponds to the first-hand data which the researcher must collect using one or multiple tools. This primary data can be obtained using methods such as surveys, online surveys, polls, interviews, questionnaires, observations, and focus group discussions. The secondary data is already published and analyzed in quantitative form through books, reports, articles, news, websites, and other sources.

This research focuses on primary data, i.e., servant leadership survey data that was collected from teachers. The data was collected through the Organizational Leadership Assessment (Laub, 1999).

\section{Demographic Characteristics}

The demographic characteristics of teachers recruited in this research are demonstrated in Table 1 shows that approximately $58.3 \%(n=211)$ of the teachers recruited in this research were females, and about $41.7 \%(n=151)$ of the teachers were male.

\section{Table 1}

Gender of Teachers

\begin{tabular}{lcccc}
\hline & Frequency & Percent & Valid Percent & Cumulative Percent \\
\hline Male & 151 & 41.7 & 41.7 & 41.7 \\
Female & 211 & 58.3 & 58.3 & 100.0 \\
Total & 362 & 100.0 & 100.0 & \\
\hline
\end{tabular}

Table 2

Age of Teachers

Age Frequency Percent Valid Percent Cumulative Percent

\begin{tabular}{lcccc}
\hline $18-25$ years & 15 & 4.1 & 4.1 & 4.1 \\
$26-35$ years & 193 & 53.3 & 53.3 & 57.5 \\
$36-45$ years & 114 & 31.5 & 31.5 & 89.0 \\
$46-55$ years & 28 & 7.7 & 7.7 & 96.7 \\
56-65 years & 11 & 3.0 & 3.0 & 99.7 \\
over 66 years & 1 & .3 & .3 & 100.0 \\
Total & 362 & 100.0 & 100.0 & \\
\hline
\end{tabular}

Table 2 indicates that approximately $53.3 \%(n=193)$ of the teachers were $26-35$ years old. Moreover, about $31.5 \%(n=114)$ of the teachers were $36-45$ years old. Additionally, the remaining 
teachers belong to different age groups. For example, about 4.1\% teachers are aged between 18-25 years $(n=15)$, about $7.7 \%$ teachers are aged between $46-55$ years $(n=28)$, and the remaining $3 \%$ teachers are aged between $56-65$ years $(n=11)$.

Figure 1 shows that approximately 48 teachers recruited in this research had eight years' experience as a full-time teacher, whereas 41 individuals possessed nine years' experience as a full-time teacher. Furthermore, about 39 teachers possessed seven years' experience, and 35 teachers had four years' experience.

\section{Figure 1}

Graph between frequency and number of years of the full-time teacher (100 indicates 1 year in the figure below).

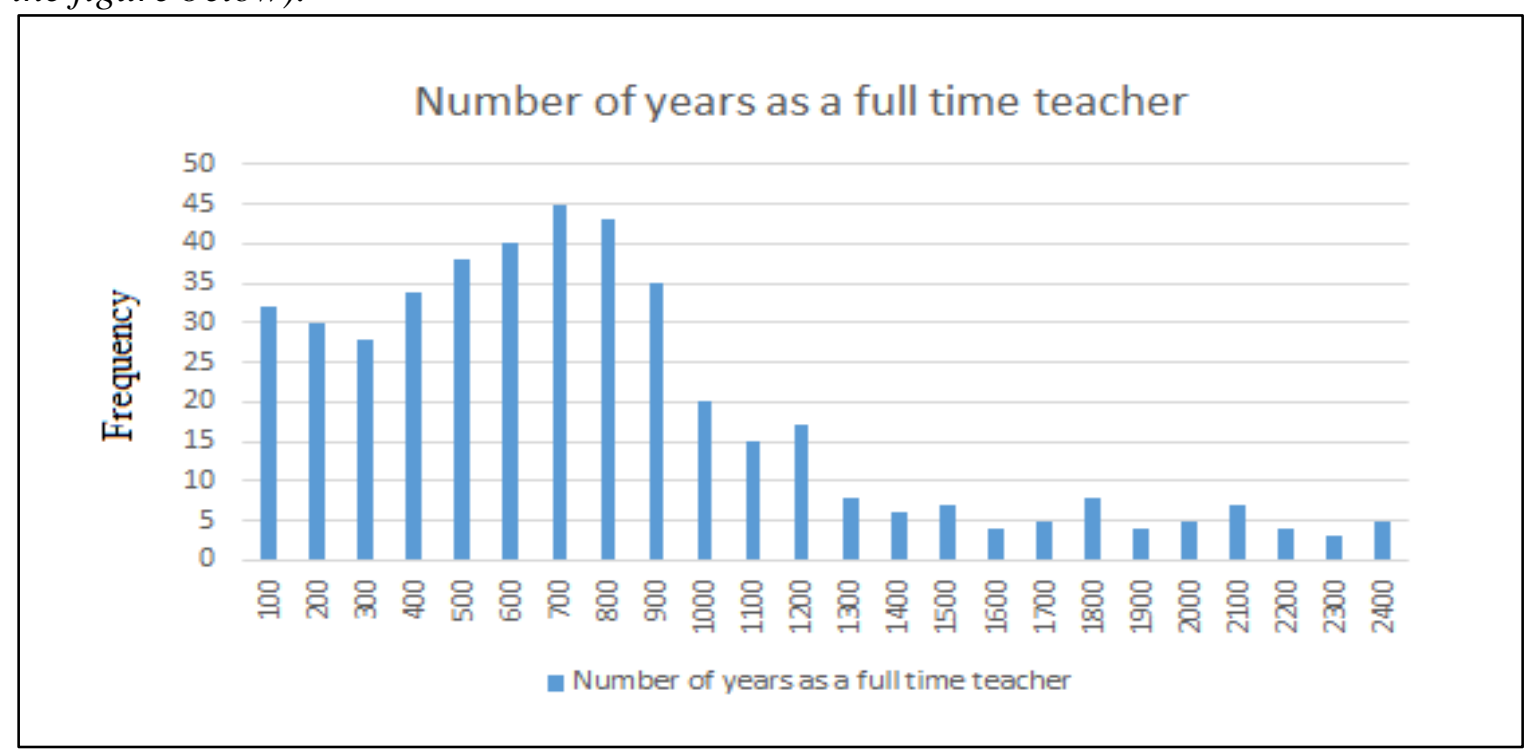

Note: Frequency and Number of Years as a Full-Time Teacher

Table 3

Descriptive Statistics

\begin{tabular}{|c|c|c|c|c|c|c|c|}
\hline & \multirow[b]{2}{*}{$\begin{array}{c}N \\
\text { Statistic }\end{array}$} & \multirow[b]{2}{*}{$\begin{array}{c}\text { Mean } \\
\text { Statistic }\end{array}$} & \multirow{2}{*}{$\begin{array}{c}\text { Std. } \\
\text { Deviation } \\
\text { Statistic }\end{array}$} & \multirow[b]{2}{*}{$\begin{array}{c}\text { Skewness } \\
\text { Statistic }\end{array}$} & \multicolumn{3}{|c|}{ Kurtosis } \\
\hline & & & & & $\begin{array}{l}\text { Std. } \\
\text { Error }\end{array}$ & Statistic & $\begin{array}{l}\text { Std. } \\
\text { Error }\end{array}$ \\
\hline Mathematics & 362 & 86.81 & 7.99 & -1.03 & .12 & -.36 & .25 \\
\hline Reading & 362 & 82.71 & 8.37 & -.19 & .12 & -1.38 & .25 \\
\hline Science & 362 & 82.74 & 8.24 & -.93 & .12 & -.11 & .25 \\
\hline$\underline{\text { Social Science }}$ & 361 & 80.07 & 14.70 & -.84 & .12 & -.14 & .25 \\
\hline Values People & 358 & 4.21 & .71 & -1.90 & .12 & 4.33 & .25 \\
\hline Develops People & 360 & 4.19 & .77 & -1.73 & .12 & 3.25 & .25 \\
\hline Builds Community & 360 & 4.22 & .65 & -1.72 & .12 & 4.21 & .25 \\
\hline Displays Authenticity & 361 & 4.16 & .79 & -1.60 & .12 & 2.67 & .25 \\
\hline Provides Leadership & 361 & 4.20 & .73 & -1.67 & .12 & 3.14 & .25 \\
\hline Shares Leadership & 359 & 4.15 & .78 & -1.81 & .12 & 3.28 & .25 \\
\hline Job Satisfaction & 361 & 4.44 & .55 & -2.26 & .12 & 8.89 & .25 \\
\hline
\end{tabular}

\section{Mathematics Achievement Scores}


Multiple regression was run between the OLA subscales and the mathematics achievement scores. As discussed earlier, only the values people subscale demonstrated a significant correlation with achievement. It was found that the values people subscale explained $1.3 \%$ of the variance in mathematics achievement scores, with a total $R=.113, R^{2}=.013$. Table 4 shows that the analysis demonstrated that the other OLA subscales did not significantly predict math scores.

\section{Table 4}

Collinearity Diagnostics for Mathematics Dependent Variable

\begin{tabular}{cccccc} 
& & \multicolumn{4}{c}{ Std. Error of the } \\
Model & $R$ & $R$ Square & Adjusted $R$ Square & Estimate & Durbin-Watson \\
\hline 1 & $.113^{\mathrm{a}}$ & .013 & .01 & 7.94 & .14 \\
\hline
\end{tabular}

Note. Dependent variable: mathematics. Predictors: (Constant), Values people.

${ }^{*} p<.05 . * * p<.01 . * * * p<.001$.

The adjusted $R^{2}$ was sufficiently close to $R^{2}$ to validate $R^{2}$ as a reliable measure of the predictability between the ten servant leadership values and the academic math scores. When considering $R^{2}$, the closer to $100 \%$ the better the predictive value of the model. In this case, the predictive value of the model was very weak. Achieving an $R^{2}$ of $\% 100$, in this case, is unachievable from a practical standpoint. This portion of the analysis suggests that the values in the servant leadership would only provide the least knowledge related to the math scores and the math score can be explained by the variables other than the independent variables. The analysis involves a large number of residuals that are unexplained by the research data. The considered model only explained $\% 1.0$ of the correlations; therefore, it was important to consider various other parameters of research for the identification of other causes for finding variations in math scores.

These alternate explanations for variations in the independent variable are associated with confounding variables. The research had not considered confounding variables because higher predictive power was expected. Other possible explanations for the variance in math achievement scores might include individual characteristics, study habits, the presence of math anxiety, and domestic issues experienced by the student.

The Durbin-Watson statistics were used for demonstrating the strength of a correlation. The Durbin-Watson statistics near to zero represent strong serial correlation. Moreover, the presence of closer numbers in the Durbin-Watson statistics represents a negative serial correlation. When the Durbin-Watson coefficient gets closer to 2, it indicates that there has been no correlation between the considered variables; therefore, the research results do not reject the null hypothesis. Analyzing the Durbin-Watson correlation in the regression between values people subscale and math scores, the coefficient is closer to zero, which demonstrated the presence of the positive correlation between these two variables. In this regard, the Durbin-Watson statistics can also be used for the determination of the strength of correlation between the two variables. In this case, there was a strong correlation.

The $R^{2}$ value and the Durbin-Watson coefficient indicated the presence of a stronger correlation between teacher values and math achievement. The Durbin-Watson coefficient requires data in natural order, for instance, the data acquired from a time series. In the case of surveys, the order in which the results are analyzed and reported is insignificant; which resulted in the absence of a time series order to the data. Table 5 presents the coefficients between the values people subscale of the OLA and the math achievement scores. 
Table 5

Coefficients for Mathematics Dependent Variable

\begin{tabular}{|c|c|c|c|c|c|c|c|c|}
\hline \multirow{2}{*}{\multicolumn{2}{|c|}{ Model }} & \multicolumn{2}{|c|}{$\begin{array}{c}\text { Unstandardized } \\
\text { Coefficients }\end{array}$} & \multirow{2}{*}{$\begin{array}{c}\begin{array}{c}\text { Standardized } \\
\text { Coefficients }\end{array} \\
\beta\end{array}$} & & \multirow[b]{2}{*}{ Sig. } & \multicolumn{2}{|c|}{$\begin{array}{l}\text { Collinearity } \\
\text { Statistics }\end{array}$} \\
\hline & & $B$ & Std. Error & & & & Tolerance & VIF \\
\hline & (Consta & 81.52 & 2.53 & & 32.22 & $.000^{* * *}$ & & \\
\hline & Values & 1.25 & .59 & .113 & 2.12 & $.034 *$ & 1.00 & 1.00 \\
\hline
\end{tabular}

Note. Dependent variable: mathematics.

$* p<.05 . * * p<.01 . * * * p<.001$.

Coefficients explore the relationship between the independent and dependent variables. The statistics indicated that the values people subscale of the OLA proved to be significant for math scores. The model predicts that for every one-point increment in the servant leader sub-scores of teachers, math scores will increase by 1.26. This coefficient values support the conclusion that higher levels of servant leadership sub-scores are predictive of higher mathematics achievement scores. The other subscale values are also correlated to other subject areas; therefore, it was essential to determine the correlations between other subscales and the study subjects.

\section{Science Achievement Scores}

The values people subscale demonstrated the presence of correlation with the science achievement scores; therefore, this subscale was considered in this analysis.

Table 6

Model Summary for Science Dependent Variable

\begin{tabular}{|c|c|c|c|c|c|c|c|c|c|c|}
\hline \multirow[b]{2}{*}{ Model } & \multirow[b]{2}{*}{$R$} & \multirow[b]{2}{*}{$R^{2}$} & \multirow[b]{2}{*}{$\begin{array}{c}\text { Adjusted } \\
R^{2}\end{array}$} & \multirow[b]{2}{*}{$\begin{array}{l}\text { Std. Error } \\
\text { of } \\
\text { Estimate }\end{array}$} & \multicolumn{5}{|c|}{ Change Statistics } & \multirow[b]{2}{*}{$\begin{array}{l}\text { Durbin- } \\
\text { Watson }\end{array}$} \\
\hline & & & & & $\begin{array}{c}R \\
\text { Square } \\
\text { Change }\end{array}$ & $\begin{array}{c}F \\
\text { Change }\end{array}$ & df1 & $\mathrm{df} 2$ & $\begin{array}{l}\text { Sig. } F \\
\text { Change }\end{array}$ & \\
\hline 1 & .229 & .052 & .050 & 7.99 & .052 & 19.26 & 1 & 349 & $.000 * * *$ & .22 \\
\hline
\end{tabular}

Note. Dependent variable: science. Predictors: (Constant), values.

$* p<.05 . * * p<.01 . * * * p<.001$.

Table 6 presents that the value of $R^{2}$ indicates that $5 \%$ of the variability in science scores can be explained by values people subscale on the OLA scale. The science scores show a stronger correlation to the values people subscale, as compared to math. The statistical values indicated that the servant leadership style of teaching demonstrated the strong correlation with the achievement of students in science.

Table 7 demonstrates that the variable is significant at $p<.05$, supporting the correlation between science scores and values people subscale on the OLA. On the other hand, Table 9 represents the excluded variables in the multi-regression analysis of the science achievement scores. The scores demonstrated no collinearity because only the values people subscale indicated the presence of positive correlation with the science achievement scores.

Table 7

Coefficients for Science Dependent Variable 


\begin{tabular}{|c|c|c|c|c|c|c|c|c|}
\hline \multirow[b]{2}{*}{ Model } & & \multicolumn{2}{|c|}{$\begin{array}{c}\text { Unstandardized } \\
\text { Coefficients }\end{array}$} & \multirow{2}{*}{$\begin{array}{c}\text { Standardized } \\
\text { Coefficients } \\
\beta \\
\end{array}$} & \multirow[b]{2}{*}{$t$} & \multirow[b]{2}{*}{ Sig. } & \multicolumn{2}{|c|}{$\begin{array}{l}\text { Collinearity } \\
\text { Statistics }\end{array}$} \\
\hline & & B & Std. Error & & & & Tolerance & VIF \\
\hline 1 & (Constant) & 71.80 & 2.54 & & 28.19 & $.000^{* * *}$ & & \\
\hline & Values & 2.61 & .59 & .22 & 4.39 & $.000^{* * *}$ & 1.00 & 1.00 \\
\hline
\end{tabular}

Note. Dependent variable: science. Predictors: (Constant), values.

$* p<.05 . * * p<.01 . * * * p<.001$.

Table 8

Excluded Variables from the Regression Model Predicting Science Achievement Scores

\begin{tabular}{|c|c|c|c|c|c|c|c|}
\hline \multirow[b]{2}{*}{ Model } & \multirow[b]{2}{*}{ Beta In } & \multirow[b]{2}{*}{$t$} & \multirow[b]{2}{*}{ Sig. } & \multirow[b]{2}{*}{$\begin{array}{c}\text { Partial } \\
\text { Correlation }\end{array}$} & \multicolumn{3}{|c|}{ Collinearity statistics } \\
\hline & & & & & Tolerance & VIF & $\begin{array}{l}\text { Minimum } \\
\text { Tolerance }\end{array}$ \\
\hline 1 Develops People & $-.009^{b}$ & -.05 & .95 & -.00 & .12 & 8.12 & .12 \\
\hline Builds Community & $-.003^{b}$ & -.02 & .98 & -.00 & .14 & 6.97 & .14 \\
\hline $\begin{array}{l}\text { Displays } \\
\text { Authenticity }\end{array}$ & $-.029^{b}$ & -.19 & .84 & -.01 & .12 & 8.34 & .12 \\
\hline $\begin{array}{l}\text { Provides } \\
\text { Leadership }\end{array}$ & $.010^{\mathrm{b}}$ & .08 & .93 & .00 & .19 & 5.22 & .19 \\
\hline Shares Leadership & $-.074^{\mathrm{b}}$ & -.51 & .61 & -.02 & .12 & 7.76 & .12 \\
\hline
\end{tabular}

Note. ${ }^{*} p<.05 . * * p<.01 .{ }^{* * *} p<.001$.

Table 9 represents the value of condition index 11.85, which indicated that there was no collinearity among the dependent variable, science, and the values people subscale.

Table 9

Collinearity Diagnostics for Science Dependent Variable

\begin{tabular}{cccccc}
\hline & & & & \multicolumn{2}{c}{ Variance proportions } \\
\cline { 5 - 6 } Model & Dimension & Eigenvalue & Condition Index & (Constant) & Values \\
\hline 1 & 1 & 1.98 & 1.00 & .01 & .01 \\
& 2 & .01 & 11.85 & .99 & .99 \\
\hline
\end{tabular}

Note. Dependent variable: science.

$* p<.05 . * * p<.01 . * * * p<.001$.

\section{Social Science Achievement Scores}

The social science scores demonstrated patterns and correlations similar to science scores. The strength of correlations for math and science scores was approximately four times higher than the math scores. The math scores demonstrated a strong correlation with the values people subscale. As shown in Table 10, for social science $R^{2}$ demonstrates that the values people subscale explained approximately $5 \%$ of the variability in the scores. The correlation is not significant at a $p<.05$. The statistical values presented that the servant leadership style of teacher demonstrated a correlation with the achievement of student in social science. The subscales other than the values people subscale were excluded in the SPSS software because the statistical test presented no significant 
correlations. The values people subscale did not demonstrate collinearity with any of the other subscales for the social science achievement scores. Table 11 indicates that the variable is significant at $p<.05$, supporting the correlation between scores for social science and values people subscales on the OLA.

Table 10

Model Summary for Social Science Dependent Variable

\begin{tabular}{|c|c|c|c|c|c|c|c|c|c|c|}
\hline \multirow[b]{2}{*}{ Model } & \multirow[b]{2}{*}{$R$} & \multirow[b]{2}{*}{$\begin{array}{c}R \\
\text { Square } \\
\end{array}$} & \multirow[b]{2}{*}{$\begin{array}{c}\text { Adjusted R } \\
\text { Square }\end{array}$} & \multirow{2}{*}{$\begin{array}{l}\text { Std. Error } \\
\text { of the } \\
\text { Estimate }\end{array}$} & \multicolumn{5}{|c|}{ Change Statistics } & \multirow[b]{2}{*}{$\begin{array}{l}\text { Durbin- } \\
\text { Watson } \\
\end{array}$} \\
\hline & & & & & $\begin{array}{c}\text { R Square } \\
\text { Change }\end{array}$ & $\begin{array}{c}F \\
\text { Change }\end{array}$ & df1 & df2 & $\begin{array}{l}\text { Sig. } F \\
\text { Change }\end{array}$ & \\
\hline$\overline{1}$ & $.228 \mathrm{a}$ & .05 & .04 & 14.23 & .05 & 19.02 & 1 & 348 & $.000 * * *$ & .20 \\
\hline
\end{tabular}

Note. Predictors: (Constant), values.

$* p<.05 . * * p<.01 . * * * p<.001$.

\section{Table 11}

Coefficients for Social Science Dependent Variable

\begin{tabular}{|c|c|c|c|c|c|c|c|}
\hline \multirow[b]{2}{*}{ Model } & \multicolumn{2}{|c|}{$\begin{array}{c}\text { Unstandardized } \\
\text { Coefficients }\end{array}$} & \multirow{2}{*}{$\begin{array}{c}\text { Standardized } \\
\text { Coefficients } \\
\text { Beta }\end{array}$} & \multirow[b]{2}{*}{$t$} & \multirow[b]{2}{*}{ Sig. } & \multicolumn{2}{|c|}{$\begin{array}{c}\text { Collinearity } \\
\text { Statistics }\end{array}$} \\
\hline & $B$ & Std. Error & & & & Tolerance & VIF \\
\hline (Constant) & 60.77 & 4.53 & & 13.39 & $.000 * * *$ & & \\
\hline Values & 4.63 & 1.06 & .22 & 4.36 & $.000 * * *$ & 1.00 & 1.00 \\
\hline
\end{tabular}

Note. Dependent variable: social science.

$* p<.05 . * * p<.01 . * * * p<.001$

Table 12

Excluded Variables from the Regression Model Predicting Social Science Achievement Scores

\begin{tabular}{|c|c|c|c|c|c|c|c|}
\hline \multirow[b]{2}{*}{ Model } & \multirow[b]{2}{*}{ Beta In } & \multirow[b]{2}{*}{$t$} & \multirow[b]{2}{*}{ Sig. } & \multirow[b]{2}{*}{$\begin{array}{c}\text { Partial } \\
\text { Correlation }\end{array}$} & \multicolumn{3}{|c|}{ Collinearity Statistics } \\
\hline & & & & & Tolerance & VIF & $\begin{array}{l}\text { Minimum } \\
\text { Tolerance }\end{array}$ \\
\hline Develops People & $.076 \mathrm{~b}$ & .51 & .61 & .02 & .12 & 8.16 & .12 \\
\hline Builds Community & $-.008 b$ & -.05 & .95 & -.00 & .14 & 6.99 & .14 \\
\hline $\begin{array}{l}\text { Displays } \\
\text { Authenticity }\end{array}$ & $.082 b$ & .54 & .58 & .02 & .12 & 8.33 & .12 \\
\hline $\begin{array}{l}\text { Provides } \\
\text { Leadership }\end{array}$ & $.070 \mathrm{~b}$ & .58 & .56 & .03 & 19 & 5.22 & .19 \\
\hline Shares Leadership & $-.113 b$ & -.77 & .43 & -.04 & .12 & 7.76 & .12 \\
\hline
\end{tabular}

Note. Predictor (Constant): values.

${ }^{*} p<.05 . * * p<.01 . * * * p<.001$. 
Table 12 presents the excluded variables in the multi-regression analysis of the social science achievement scores. The scores demonstrated no collinearity because only the values people subscale indicated the presence of correlation with the social science achievement scores.

Table 13 represents the value of condition index 11.85, which represented that there was no collinearity among the dependent variable, science, and the values people subscale.

Table 13

Collinearity Diagnostics for Social Science Dependent Variable

\begin{tabular}{cccccc} 
& & & & \multicolumn{2}{c}{ Variance proportions } \\
\cline { 5 - 6 } Model & Dimension & Eigenvalue & Condition Index & (Constant) & values \\
\hline 1 & 1 & 1.986 & 1.000 & .01 & .01 \\
& 2 & .014 & 11.838 & .99 & .99 \\
\hline
\end{tabular}

Note. Dependent variable: social science.

\section{Reading Achievement Score}

The reading scores demonstrated a strong correlation with the values people subscale. For reading achievement score, $R^{2}$ demonstrates that the values people subscale explained approximately $5 \%$ of the variability in the scores. The correlation is not significant at a $p<.05$ confidence level. However, the statistical values presented that the servant leadership style of teacher demonstrated a positive correlation with the achievement of student in science. The subscales other than the values people subscale were excluded in the SPSS analysis because the statistical test presented no significant correlations.

This study has provided important support that the values people subscale exhibits a positive correlation at least to a certain degree, with increases in achievement scores in math, science, and social science. The study failed to find that the other subscales on the Organizational Leadership Assessment (OLA) are significantly related to achievement scores. However, examining the statistical results alone is only one aspect of addressing the research questions; one must also examine the results in the context of what they mean regarding servant leadership in the classroom.

\section{Discussion and Conclusion}

According to the results of this research, it is identified that a strong correlation exists between students' science achievement scores and students' social science achievement scores with servant leadership values people. The correlation results indicated that there exists strong correlation among all four variables with servant leaders; however, only two variables have strong correlation with the values people subscale.

One contribution of this study is that, through these findings, it is put forward that higher values of servant leadership in schools result in attaining higher values of student achievement scores for science and social science. School administrators who aim to improve the performance of students should work on improving the servant leadership values of their teachers through seminars and workshops. However, in the selection of new teachers during the hiring process, it is important to consider the servant leadership characteristics of potential teachers who are attempting to enter the profession. Perhaps education departments at colleges should administer a screening 
survey to potential students that assesses their candidacy through the lens of the servant leadership values identified in this study.

Farida et al. (2020) indicated in their study that the mediating role of trust in the relationship between servant leadership and performance. They improved the attention in two ways: first way is defined trust as bi-dimensional and the second one is to look at performance in individual level. The study was intended to expansion the knowledge on new domain of servant leadership, especially on performance in an individual level.

The goal was to examine individual performance of work environment, and how servant leadership affects performance, hypothesizing the mediating role of bi-dimensional trust. Overall, they found strong support for affective trust to succeed and mediate positively regarding the relationship between servant leadership and individual performance.

Sendjaya et al. (2008) indicated that the results of correlation statistics support the findings of researchers who argued that the servant leadership style was found to be one of the most appropriate approaches for leadership in education. They also noted, servant leaders feel that the role they play is to help people achieve their goals. Considering the environment of educational institutes, this leadership aligns with the responsibilities of teachers within the educational institutes. The concepts of servant leadership can be applied in educational institutions for developing leadership among students, with the intention of transforming students into pillars of success in society (Russell \& Stone 2002).

\section{Servant Leadership and Students' Mathematic Achievement Scores}

According to the results of first hypothesis testing, it is identified that in the selected schools, the servant leadership of school teachers does not influence students' math achievement scores. Mathematics achievement scores, with a total $R=.113, R^{2}=.013$, do not support the hypothesis and reject the alternative hypothesis. The analysis demonstrated that the other OLA subscales did not significantly predict math scores.

\section{Servant Leadership and Students' Science Achievement Scores}

The second research hypothesis testing identified that in the selected schools, the servant leadership of school teachers positively affects students' science achievement scores. The results support the hypothesis and accept the alternative hypothesis. Moreover, a strong correlation is also identified between servant leadership and students' science achievement scores.

\section{Servant Leadership and Students'Social Science Achievement Scores}

The third research hypothesis testing identified that in the selected schools, the servant leadership of school teachers positively affects students' social science achievement scores. The results attained accept the alternative hypothesis. Moreover, a strong correlation is identified between these two variables.

\section{Servant Leadership and Students’ Reading Achievement Scores}

The last research hypothesis testing identified that the servant leadership of school teachers positively affects students' reading achievement scores. The results support the hypothesis and 
accept the alternative hypothesis. However, a weak correlation is identified between these two variables.

Focusing on the results, it can be put forward that different aspects result in teacher inefficiencies that do not affect student achievement, neither in a positive way nor in a negative way. The first reason for this could be the organizational culture. It is the set of habits and beliefs established through values, norms, and attitudes shared by the members of the organization; these are the principles that express the identity of the organization (Russell, 2001). Thus, from the leadership in schools, it might be that the organizational culture of the schools promotes servant leadership skills. Furthermore, Russell and Stone (2002) found that because of its ability to spread from superior to subordinate, servant leadership can positively impact the culture and performance of an organization as well. The authors propose in their model of servant leadership that the spreading of positive qualities (e.g., vision, values) "will lead directly to improved organizational culture and then to increased employee attitudes and performance" (p. 238). It is possible that in sample schools, teachers and school leadership face barriers to having effective staff and practices for teaching mathematics to the students. Therefore, student achievement scores indicated that there is not influence of leadership practices as depicted by either a positive trend or a negative trend. It might also be a result of ineffective staff training. Hiring practices could also be a factor. It could be that, in hiring, the school administrators carefully screened applicants to make sure that they possessed servant leadership qualities (Duffy, 2018; Yong, 2013).

In the light of the research findings, several statistical measures presented in the results section of the study were obtained. In the findings of the study, the standard deviation is the average difference of the scores from the mean scores (Appendix E, Table 4, 5 and 6). The study also found that leadership models vary according to the characteristics of schools. In most school systems, one would expect to see a larger degree of variability than appears in this sample; that is, one would expect to find a mix of personalities and leadership styles within a school district. This would produce a higher standard deviation than was seen in this sample set.

The question is whether the low standard deviation scores and consistent results are a reflection of the characteristics of the teachers within the school system, as has already been discussed, or whether there is another explanation for the consistent answers that were obtained on the subscales. It is possible that the school system hires and trains their teachers in such a manner that produces a high degree of servant leadership within the system (Thompson, 2015). It could also be that those who already possessed a high level of servant leadership regarding the values people subscale and the high degree of caring for the outcome of the school community were the ones who volunteered to take the test. In this case, the low degree of standard deviation from the mean may be a result of sample bias-even though the researcher used random sampling techniques and was not in control of the final sample makeup (Russell \& Stone, 2002). If this is the case, it means that the results of the study reflect only the teachers who have a high level of servant leadership qualities, and those other teachers within the school system who do not possess these qualities are not reflected in the results (Spears, 2010). Heyler and Martin (2018) emphasized that a person's level of integrity should also be a better predictor of their decisions than their age or education level. Liu (2019) also indicated that regarding the organizational leadership studies, the leader's role as a servant, putting the needs of others first to therefore promote positive outcomes for the organizations.

The only way to test and determine if sample bias has occurred in the current research study would be to re-administer the Organizational Leadership Assessment (OLA) to a higher number of teachers within the district. Here, OLA is the independent variable, to be correlated with student achievement, which is the dependent variable. Students' academic achievement was defined based 
on standardized test results in Houston. However, if the retest results were the same, then it would suggest that perhaps the school culture is what promotes a high level of servant leadership. If the retest results were different, even though a random sampling technique was used, it would indicate that there might be some degree of sample bias in the current study. Consequently, re-administering the test would help to improve the reliability of the survey instrument (Wong \& Cummings, 2009).

\section{Values People Subscale}

The values people subscale is the only subscale that demonstrated any substantial correlation with academic achievement is substantial when one considers the meaning of the values people subscale. The scale indicates how much a teacher values people. The OLA describes this value as being perceived by the receiver with an implicit sense that they are being valued by the other person (Crippen, 2010). This establishes trust between the leader and the follower (Wong \& Cummings, 2009). Servant leaders who value others project this onto those who they lead (Fields et al., 2015). In the classroom, this translates into a sense that students get from a teacher of how much the teacher cares about them as individuals (Barrow \& Mirabella, 2009; Novak, 2013).

When students feel that a teacher cares about them, they are more likely to respond by being more engaged and active in the classroom (Hamdan et al., 2013; Noland \& Richards, 2015). In addition, the values people subscale demonstrates how much the teacher serves others first, before serving themselves. This translates into a dedicated teacher who puts the needs of his or her students first. The values people subscale also measures how much a servant leader believes and trusts in people. Another component of the subscale is the ability to listen respectfully to others (Yong, 2013).

Bandura's social learning theory, which states that people learn from observations, limitations, and modeling, was used as the theoretical framework of this study. The theory is based on the fact that there are types of learning where direct reinforcement is not the main teaching mechanism, but rather it is the social element that can lead to the development of new learning among individuals. The social learning theory is useful in explaining that how people can learn new things and develop new behaviors by observing other individuals (Phipps et al., 2013). Thus, this theory deals with the process of learning by observation among people. The implementation of this theory in the field of academics stressed the importance of observing, modeling, and presenting behaviors, attitudes, and emotional reactions towards others (Spears, 2010). Specifically considering the context of the academic environment, the teachers and other individuals at leadership levels cannot allow students to learn through trial-and-error methods. For this reason, it is crucial to analyze the factors, which can impact the learning capabilities of students (Phipps et al., 2013).

The theoretical framework developed by Bandura (1986) emphasizes that individuals possess the capability to symbolize, self-regulate, self-reflect, and learn through modeling. In the light of this theory, students enrolled in the particular educational institutes are capable of reacting towards situations. The students are also proactive and anticipative and are also able to function as the self-evaluators and regulators of their actions and motivations. For this reason, the teachers and the other academic leaders are required to adopt the most appropriate behaviors for the students, allowing them to learn the appropriate ways of initiating their behaviors during different situations (Bandura, 2001).

Different concepts related to the social cognitive theory apply to the thoughts and actions adopted by the servant leaders. The theory believes that human behavior must be described regarding the reciprocal interaction between cognitive or personal, behavioral, and environmental 
determinants. Cognitive processes are the first mediators of behavior. But people can incorporate the consequences of previous actions into their future efforts. In social cognitive theory, an essential part of behavior results from vicarious learning or imitation (Bandura, 2014). However, thought is an active element in the construction of reality by every individual. Each person constructs his reality from the interaction between the environment and cognition (Parker et al., 2009). In this sense, the information that the individual handles are crucial when establishing his behavior guidelines (Bandura, 2014).

Furthermore, some of the researchers had also analyzed the impacts of the relationships and interactions between servant leaders and their subordinates. The social cognitive theory proposed by Bandura also assists in understanding the concept of servant leadership from an academic point of view. This theory states that a wide majority of behaviors learned by different individuals are learned through observations. In this manner, the teachers are role models for the students; therefore, the efficacy of the skills of students is dependent on the capability of teachers. Despite influencing the thought processes of the students, teachers also positively contribute to the creation of a learning atmosphere at the school (Jennings, 2002).

As described in the literature, the leadership traits of a teacher indicated by the values people subscale, and the learning behavior of the students depicted by Bandura's social learning theory, it has been found that the math, science, and social science achievement scores of the students considerably improved (Van Dierendonck, 2011).

The correlations between the values people subscale and improvements in social science and science scores are noteworthy when one considers them in the context of what that subscale represents.

Keith (2014) indicated that servant leaders motivated on serving, growing people, and always considering the benefit and needs of people. These values are ethical and effective regarding servant leadership. In order to improve the ethics and make the institution functioning, the servant leadership has to be modeled as we indicated in bandura's theory.

\section{Limitation of the Study}

This research is limited to the fifteen public schools in Houston, Texas. The results may not be generalizable to other public schools. The study is also limited to the school teachers who have agreed to participate in the study. There may be many other variables that impact students' academic achievement in these schools, but in this study, the independent variable is the servant leadership behavior of school teachers, and the dependent variable is student achievement. The data to measure student achievement was taken from the 2015-2016 school years.

\section{References}

Al-Mahdy, Y. F., Al-Harthi, A. S., \& Salah El-Din, N. S. (2016). Perceptions of school principals' servant leadership and their teachers' job satisfaction in Oman. Leadership and Policy in Schools, 15(4), 543-566.

Bandura, A. (1977). Social learning theory. Prentice Hall.

Bandura, A. (1986). Social foundations of thought and action: A social cognitive theory. Prentice Hall.

Bandura, A. (2001). Social cognitive theory: An agentic perspective. Annual Review of Psychology, $52,1-26$. 
Bandura, A. (2014). Social cognitive theory of moral thought and action. In W. M. Kurtines \& J. L. Gewirtz (Eds.), Handbook of moral behavior and development (Vol. 1, pp. 45-103). Lawrence Erlbaum Associates.

Barrow, L. M. S., \& Mirabella, J. (2009). An empirical study of other-oriented and rational selfinterested leadership approaches. Journal of Leadership Studies, 3(2), 44-54.

Brown, S., \& Bryant, P. (2015). Getting to know the elephant: A call to advance servant leadership through construct consensus, empirical evidence, and multilevel theoretical development. Servant Leadership: Theory and Practice, 2(1), 10-35.

Creswell, J. W., \& Creswell, J. D. (2017). Research design: Qualitative, quantitative, and mixed methods approaches. Sage Publications Inc.

Crippen, C. (2010). Serve, teach, and lead: It's all about relationships. Insight: A Journal of Scholarly Teaching, 5, 27-36.

Curless, T. A. (2000). Optimization of motivational tactics in self-paced learning. Dissertation Abstracts International, 61(2), 578A.

Duffy, J. O., Wickersham-Fish, L., Rademaker, L., \& Wetzler, E. (2018). Using collaborative autoethnography to explore online doctoral mentoring: Finding empathy in mentor/protégé relationships. American Journal of Qualitative Research, 2(1), 57-76. https://doi.org/10.29333/ajqr/5794

Eggen, P., \& Kauchak, D. (1997). Educational psychology: Windows on classrooms. Prentice Hall. Elmore, R. (2000). Building a new structure for school leadership. Albert Shanker Institute.

Farida S., Yingying Z. Z., Gopinath, C., \& Ahmad A. (2020). Impact of servant leadership on performance: The mediating role of affective and cognitive trust. SAGE Open, 10(1), 1-16. https://doi.org/10.1177/2158244019900562

Fields, J. W., Thompson, K. C., \& Hawkins, J. R. (2015). Servant leadership: Teaching the helping professional. Journal of Leadership Education 14(4), 92-105.

Giannakos, M. N., Krogstie, J., \& Sampson, D. (2018). Putting flipped classroom into practice: A comprehensive review of empirical research. In D. Sampson, D. Ifenthaler, J. Spector \& P. Isaías (Eds.), Digital technologies: Sustainable innovations for improving teaching and learning (pp. 27-44). Springer. https://doi.org/10.1007/978-3-319-73417-0_2

Greenleaf, R. K. (1970). The servant as leader. The Robert Greenleaf Center.

Grisaffe, D. B., VanMeter, R., \& Chonko, L. B. (2016). Serving first for the benefit of others: Preliminary evidence for a hierarchical conceptualization of servant leadership. Journal of Personal Selling \& Sales Management, 36(1), 40-58.

Hall, N., \& Quinn, R. (2014). Parental involvement at the high school level: Parents' perspectives. Journal of Ethnic \& Cultural Studies, 1(1), 13-21.

Hamdan, N., McKnight, P., McKnight, K., \& Arfstrom, K. M. (2013). Education students' responses to flipped learning methodology in the Lebanese University. American Journal of Educational Research, 4(12) 868-871.

Heyler, G. S., \& Martin, J. A. (2018). Servant leadership theory: Opportunities for additional theoretical integration. Journal of Managerial Issues, 30(2), 230-243.

Horsman, J. H. (2001). Perspectives of servant-leadership and spirit in organizations. [Doctoral Dissertation, Gonzaga University].

Jaramillo, F., Bande, B., \& Varela, J. (2015). Servant leadership and ethics: A dyadic examination of supervisor behaviors and salesperson perceptions. Journal of Personal Selling \& Sales Management, 35(2), 108-124.

Jennings, D. (2002). Strategic management: An evaluation of the use of three learning methods. Journal of Management Development, 21(9), 655-665. 
Keith, K. M. (2014). The ethical advantage of servant leadership. Greenleaf Centre for Servant Leadership.

Laub, J. A. (1999). Assessing the servant organization: Development of the servant organizational leadership assessment (SOLA) instrument [Doctoral dissertation, Florida Atlantic University]. https://olagroup.com/Images/mmDocument/Laub\%20Dissertation\%20Complete\%2099.p df

Ledbetter, S. D. (2003). Law enforcement leaders and servant leadership: A reliability study of the organizational leadership assessment [Doctoral dissertation, Regent University]. https://www.servantleaderperformance.com/wp-content/uploads/2018/04/2003-SteveLedbetter-Dissertation.pdf

Liu, H. (2019). Just the servant: An intersectional critique of servant leadership. Journal of Business Ethics, 156, 1099-1112.

Mcalpin, E., Shilane, D., \& Kalaycioglu, S. (2019). Dynamic versus static presentation formats, do they impact performance differently? Journal of Computers in Mathematics \& Science Teaching, 38(1), 49-76

Miears, L. D. (2004). Servant-leadership and job satisfaction: A correlational study in Texas Education Agency Region X schools. Dissertation Abstracts, International, 65(9), 3237.

Noland, A., \& Richards, K. (2015). Servant teaching: An exploration of teacher servant leadership on student outcomes. Journal of the Scholarship of Teaching \& Learning, 15(6), 16-38.

Northouse, P. G. (2018). Leadership: Theory and practice. Sage Publications Inc.

Novak, D., \& Bocarnea, M. C. (2013). The leadership of organizational networks: An exploration of the relationship between leadership and social networks in organizations. In Jonathan $\mathrm{H}$. Westover (Ed.), Leadership and organizational change (pp. 195-214). Common Ground.

Panaccio, A., Henderson, D. J., Liden, R. C., Wayne, S. J., \& Cao, X. (2015). Toward an understanding of when and why servant leadership accounts for employee extra-role behaviors. Journal of Business and Psychology, 30(4), 657-675.

Parker, M. A., Ndoye, A., \& Imig, S. R. (2009). Keeping our teachers! Investigating; mentoring practices to support and retain novice educators. Mentoring \& Tutoring: Partnership in Learning, 17(4), 329-341.

Phipps, M., Ozanne, L. K., Luchs, M. G., Subrahmanyan, S., Kapitan, S., Catlin, J. R., \& Weaver, T. (2013). Understanding the inherent complexity of sustainable consumption: A social cognitive framework. Journal of Business Research, 66(8), 1227-1234.

Rasool, S., \& Zhang, J. (2020). Bangladeshi, Indian, and Pakistani Parents' Perceptions of Their Children's Academic Achievement in Southwest Florida. American Journal of Qualitative Research, 4(3), 146-160. https://doi.org/10.29333/ajqr/9337

Russell, R. F. (2001). The role of values in servant leadership. Leadership \& Organization Development Journal, 22(2), 76-83.

Russell, R. F., \& Stone, A. G. (2002). A review of servant leadership attributes: Developing a practical model. Leadership \& Organization Development Journal 23(3), 145-157.

Selladurai, R., \& Carraher, S. (2014). Servant Leadership: Research and Practice. IGI Global.

Sendjaya, S., Sarros, J. C., \& Santora, J. C. (2008). Defining and measuring servant leadership behavior in organizations. Journal of Management Studies, 45(2), 402-424.

Shaw, J., \& Newton, J. (2014). Teacher retention and satisfaction with a servant leader as principal. Education, 135(1), 101-106. 
Sousa, M., \& Van Dierendonck, D. (2016). Introducing a short measure of shared servant leadership impacting team performance through team behavioral integration. Frontiers in Psychology, 6, 20-29.

Spears, L. C., \& Lawrence, M. (Eds.). (2016). Practicing servant-leadership: Succeeding through trust, bravery, and forgiveness. John Wiley \& Sons.

Spears, L. C. (2010). The character and servant leadership: Ten characteristics of effective, caring leaders. Journal of Virtues \& Leadership, 1(1), 25-30.

Spears, L. C. (2005). The understanding and practice of servant-leadership. The International Journal of Servant Leadership, 1(1), 29-45.

Thompson, R. S. (2015). The perception of servant leadership characteristics and job satisfaction in a church-related college [Doctoral dissertation, Indiana State University].

Van Dierendonck, D. (2011). Servant leadership: A review and synthesis. Journal of Management, 37(4), 1228-1261.

Winston, B., \& Fields, D. (2015). Seeking and measuring the essential behaviors of servant leadership. Leadership \& Organization Development Journal, 36(4), 413-434.

Wong, C. A., \& Cummings, G. G. (2009). The influence of authentic leadership behaviors on trust and work outcomes of healthcare staff. Journal of Leadership Studies, 3(2), 6-23.

Yang, Z., Zhang, H., Kwan, H. K., \& Chen, S. (2018). Crossover effects of servant leadership and job social support on employee spouses: The mediating role of employee organizationbased self-esteem. Journal of Business Ethics, 147(3), 595-604.

Yong, B. (2013). The relationship between emotional intelligence, motivation, integrity, spirituality, mentoring and servant leadership practices. Arts and Social Sciences Journal, 67, 1-20.

\section{Notes on Contributors}

Harun Gultekin received his doctoral degree in educational leadership from Alvernia University. Currently, he is teaching at Lehigh Carbon Community College in Schnecksville, Pennsylvania. His research expertise are leadership studies, servant leadership, and students' academic achievement. He published several books and numerous peer-reviewed articles. ORCID ID\# https://orcid.org/0000-0001-7212-2742

Sister Margaret Anne received her Ph.D. from Temple University in Educational Policy and Leadership from Ohio State. She is a member of the Graduate faculty at Alvernia University in Reading, Pennsylvania. In her twelve years at Alvernia Sister Margaret Anne served as an Executive in residence, Interim Provost and Vice President for University Life. She recently went to full time faculty status as an Associate Professor in the Education Department. Sister currently teaches educational administration at both the Masters and Doctoral level. Prior to her time at Alvernia Sister Margaret Anne served as President of Chatfield College in Cincinnati and Vice President for Student Services at Gwynedd Mercy College (now University!). In addition to her work in higher education Sister also served as an elementary principal and teacher. ORCID ID\# https://orcid.org/0000-0002-2935-3374. 